Open Access

\title{
An N-terminal antibody promotes the transformation of amyloid fibrils into oligomers and enhances the neurotoxicity of amyloid-beta: the dust-raising effect
}

\author{
Yu-Hui Liu ${ }^{\dagger}$, Xian-Le Bu ${ }^{\dagger}$, Chun-Rong Liang, Ye-Ran Wang, Tao Zhang, Shu-Sheng Jiao, Fan Zeng, Xiu-Qing Yao, \\ Hua-Dong Zhou, Juan Deng and Yan-Jiang Wang*
}

\begin{abstract}
Background: Senile plaques consisting of amyloid-beta $(A \beta)$ are the major pathological hallmark of Alzheimer's disease (AD) and have been the primary therapeutic target. Immunotherapies, which are designed to remove brain $A \beta$ deposits, increased levels of soluble $A \beta$ and accelerated brain atrophy in some clinical trials, suggesting that the solubilization of $A \beta$ deposition might facilitate the formation of more toxic $A \beta$ oligomers and enhance neurotoxicity.

Methods: The capacity of antibodies against different epitopes of $A \beta$ to disaggregate preformed $A \beta$ fibrils was investigated. The co-incubation of antibodies and $A \beta$ fibrils was then tested for neurotoxicity both in vitro and in vivo.

Results: After the incubation of preformed $A \beta$ fibrils with the N-terminal antibody $6 E 10$, the fibrils were decreased, while the oligomers, mostly dimers and trimers, were significantly increased. However, no such effects were observed for antibodies targeting the middle domain (4G8) and C-terminus of $A \beta$ (8G7). The co-incubates of preformed $A \beta$ fibrils with 6E10 were more neurotoxic, both in vitro and in vivo, than the co-incubates with 4G8 and 8G7.
\end{abstract}

Conclusions: Our results indicate that the antibody targeting the $\mathrm{N}$-terminus of $\mathrm{A} \beta$ promoted the transformation of $A \beta$ from fibrils into oligomers and increased neurotoxicity. Immunotherapies should take into consideration the enhanced neurotoxicity associated with the solubilization of $A \beta$ deposits by antibodies against the Nterminus of $A \beta$.

Keywords: Alzheimer, Amyloid-beta, N-terminal antibody, Oligomer, Fibril, Dust-raising effect

\section{Introduction}

Senile plaque containing amyloid-beta $(A \beta)$ protein are a major hallmark of Alzheimer's disease (AD) and have been considered as an important therapeutic target of $\mathrm{AD}[1,2]$. Immunotherapies are promising for the treatment of $\mathrm{AD}$ by removing senile plaques and attenuating the pathologies secondary to $A \beta$, such as tau pathologies, neuroinflammation, dendritic dysfunction and neuronal loss [3]. However, current clinical trials of immunotherapies for $\mathrm{AD}$ failed to

\footnotetext{
* Correspondence: yanjiang_wang@tmmu.edu.cn

${ }^{\dagger}$ Equal contributors

Department of Neurology and Centre for Clinical Neuroscience, Daping Hospital and Research Institute of Surgery, Third Military Medical University, 10 Changjiang Branch Road, Yuzhong District, Chongqing 400042, China
}

improve cognition and reverse disease progression. Several significant adverse effects were observed in $\mathrm{AD}$ clinical trials, including meningoencephalitis, vasogenic oedema and microhaemorrhage [4]. Some immunotherapies could not reduce or even increased the levels of soluble $A \beta$ in both animal and clinical trials $[5,6]$. It was suggested that oligomers are the most toxic form of $A \beta$ aggregates [7]. In this regard, the transformation of $A \beta$ oligomers into fibrils might be an adaptive change in $\mathrm{AD}$; disaggregation $\mathrm{A} \beta$ fibrils into oligomers in immunotherapies may enhance the neurotoxicity of this peptide. This might explain the failure of AN1792 clinical trials in which alleviation of the brain amyloid burden was accompanied by accelerated brain atrophy and the deterioration of cognitive function in 
patients receiving the vaccine [8]. In the present study, we aimed to investigate the capacity of antibodies targeting different epitopes of $A \beta$ to disaggregate preformed $A \beta$ fibrils and to determine whether antibody-induced disaggregation of $A \beta$ fibrils can facilitate the formation of oligomers and enhance the neurotoxicity of $A \beta$.

\section{Materials and methods Preparation of $A \beta$ fibrils}

Synthetic A $\beta 42$ was purchased from American Peptide (CA, USA). A $\beta$ fibrils were prepared according to previous protocols [9]. Briefly, A $\beta 1-42$ was dissolved in $100 \mu \mathrm{L}$ of ice-cold Dulbecco's modified Eagle's medium (DMEM, Gibco) $(\mathrm{pH}=7.5)$ containing $0.05 \% \mathrm{NaN}_{3}$. Solutions containing $10 \mu \mathrm{g}$ of A $\beta 42$ were incubated at $37{ }^{\circ} \mathrm{C}$ for $72 \mathrm{~h}$ for polymerization. The reaction tubes were not agitated during the reaction. After incubation, the mixture was centrifuged at $4{ }^{\circ} \mathrm{C}$ for $20 \mathrm{~min}$ at $8000 \times g$. The supernatant was discarded, and the precipitation was resuspended in $50 \mu \mathrm{L}$ of phosphate-buffered saline (PBS) containing $0.05 \% \mathrm{NaN}_{3}$ in an Eppendorf tube and stored at $4{ }^{\circ} \mathrm{C}$ for further use.

\section{Preparation of antibody-A $\beta$ co-incubates}

The monoclonal antibodies used in the present study, including 6E10 (antigen epitope, $A \beta$ residues 1-17; affinity to $\mathrm{A} \beta$ monomer, $22.3 \mathrm{nM}$ [10]; Covance), 4G8 (antigen epitope, $\mathrm{A} \beta$ residues 17-24; affinity to $\mathrm{A} \beta$ monomer, 30.1 nM [10]; Covance) and 8G7 (antigen epitope, $\mathrm{A} \beta$ residues 41-42; Acris), were dissolved in distilled water at a concentration of $1 \mu \mathrm{g} / \mu \mathrm{L}$. Preformed $\mathrm{A} \beta$ fibrils generated from $10 \mu \mathrm{g}$ of $\mathrm{A} \beta 42$ were resuspended in $9 \mu \mathrm{L}$ of distilled water, followed by the addition of $1 \mu \mathrm{L}$ of antibody solution. A $\beta$ fibril suspensions with $1 \mu \mathrm{L}$ PBS were incubated under the same conditions as a control. The mixture was incubated at $37^{\circ} \mathrm{C}$ for $72 \mathrm{~h}$ before the assay.

\section{Thioflavin T assay}

To test whether antibodies, including 6E10, 4G8 and $8 \mathrm{G} 7$, can disaggregate $\mathrm{A} \beta$ fibrils, $\mathrm{A} \beta 42(10 \mu \mathrm{M})$ was dissolved in distilled water and incubated in 96-well plates at $37{ }^{\circ} \mathrm{C}$ for $48 \mathrm{~h}$ for fibrillization. Antibodies $(2 \mu \mathrm{g}$ in $1 \mu \mathrm{L}$ ) were then added to the wells, and the samples were incubated at $37{ }^{\circ} \mathrm{C}$ for another $72 \mathrm{~h}$. A $\beta 42$ monomers were incubated with PBS under the same conditions as the negative control. The samples were then measured by adding $5 \mu \mathrm{M}$ thioflavin $\mathrm{T}$ (ThT) solution (50 mM phosphate buffer, pH 6.0). Fluorescence intensity was monitored at an excitation wavelength of $450 \mathrm{~nm}$ and an emission wavelength of $482 \mathrm{~nm}$ by a spectrometer (Synergy H4, Bio Tek). Each experiment was performed in triplicate, and the means of the triplicates were used for the statistical analysis.

\section{Western blot}

A $10-\mu \mathrm{L}$ aliquot of the co-incubation samples as described above was loaded onto SDS-PAGE gradient (4 \%-10 \%$16 \%$ acrylamide) gels. Separated A $\beta$ s were transferred to nitrocellulose membranes. The blots were probed with biotin-conjugated 6E10. Infrared dye-conjugated streptavidin (Li-COR Biosci, NE) was used to detect positive bands. The membranes were visualized with an Odyssey Imaging System (Odyssey V3.0). The density was calculated with western blot analysis software (Quantity One V4.62).

\section{Transmission electron microscopy negative staining}

To validate the effect of antibodies on the disaggregation of $\mathrm{A} \beta$ fibrils, transmission electron microscopy (TEM) negative staining was performed. A $10-\mu \mathrm{L}$ aliquot of preformed A $\beta 42$ fibrils that were co-incubated with antibodies (as prepared above) was spotted onto a glow-discharged, carbon-coated Formvar grid and incubated for $20 \mathrm{~min}$ at room temperature. The droplet then was displaced with an equal volume of $2.5 \%(v / v)$ glutaraldehyde and incubated for an additional $6 \mathrm{~min}$. Finally, the peptide was stained with $2 \%$ aqueous phosphotungstic acid for $30 \mathrm{~s}$. Samples were examined using a Joel 1200 EX transmission electron microscope equipped with a Megaview 3 digital camera. The area of fibrils was selected for automatic quantification using Image J software, and the analysis yielded the fractional area of the total positive staining against the area of the analysed field.

\section{Annexin V labelling}

An annexin V staining kit (KeyGEN BioTECH) was used according to the manufacturer's instructions to evaluate the proportion of apoptotic cells. Briefly, SH-SY5Y cells were seeded at a density of $10^{5}$ cells $/ \mathrm{mL}$ in 12 -well plates (Sarstedt) in DMEM (Gibco) containing 10 \% foetal bovine serum (FBS, Gibco) at $200 \mu \mathrm{L}$ per well. The coincubates $(20 \mu \mathrm{L})$ of different antibodies or PBS were added to the wells. After $3 \mathrm{~h}$ of incubation, live cells were washed three times with warm PBS for $5 \mathrm{~min}$. Then, they were treated with FITC-labelled annexin V for $5 \mathrm{~min}$ at room temperature and subsequently washed with PBS. The cells were then incubated with DAPI (1:1000) for $5 \mathrm{~min}$ at room temperature and washed with PBS. Cell images were collected with a B50 fluorescence microscope.

\section{MTT assays}

The neurotoxicity of the co-incubation samples was measured using an MTT (3-(4,5-dimethylthiazol-2-yl)-2,5diphenyl tetrazolium bromide) viability assay as previously described [11]. Briefly, SH-SY5Y cells were seeded at a density of $10^{5}$ cells/mL in a 96-well plate in DMEM containing $10 \% \mathrm{FBS}$ at $50 \mu \mathrm{L}$ per well. The co-incubates 
$(10 \mu \mathrm{L})$ were added to the wells. After $20 \mathrm{~h}$ of incubation, $10 \mu \mathrm{L}$ of MTT (Sigma-Aldrich, USA, $5 \mathrm{mg} / \mathrm{mL}$ in PBS) was added to each well, and the samples were incubated for $4 \mathrm{~h}$. A solubilization solution (10\% SDS in $0.01 \mathrm{M}$ hydrochloric acid) was added to dissolve the insoluble purple formazan product to produce a coloured solution. Each assay was performed in triplicate. The optical density (OD) was read at $600 \mathrm{~nm}$ on a multi-well scanning spectrophotometer (BIO-RAD Model 2550 EIA Reader).

\section{Neurite outgrowth assay}

For the neurite outgrowth assays, SH-SY5Y cells were cultured for 7 days in a medium with $1 \%$ FBS and $10 \mu \mathrm{M}$ all-trans-retinoic acid (RA) (Sigma, USA) and then incubated with $2 \mu \mathrm{L}$ of the co-incubates for $24 \mathrm{~h}$. Each assay was performed in triplicate. The cell images were taken by microscopy, and the length of 10 neurites per view field were measured. Data from 20 view fields per group were analysed.

\section{Mouse and brain injections of antibody- $A \beta$ co-incubates}

Six-month-old C57BL/6J mice were housed and maintained in the animal facility at Daping Hospital. We used only females in our analyses $(n=5$ for each antibody group). A midsagittal incision was made to expose the cranium, and a burr hole was drilled with a dental drill over the left hemisphere to the following coordinates: anteroposterior, $-0.2 \mathrm{~mm}$; lateral, $1 \mathrm{~mm}$; and ventral, $2.2 \mathrm{~mm}$, which were all taken from the bregma. Co-incubates $(5 \mu \mathrm{L})$ were injected into the lateral ventricle of the mice. PBS $(5 \mu \mathrm{L})$ was injected in the same manner as a control. Forty-eight hours after injection, the brains were fixed and sectioned. Five sections around the injection site were selected per animal. This study and all experimental protocols were approved, and the methods were carried out in accordance with the guidelines of the Animal Care Committee of the Third Military Medical University (TMMU).

\section{Analysis of neuronal apoptosis}

To detect apoptotic cells, terminal deoxynucleotidyl transferase dUTP nick end labelling (TUNEL) staining and immunofluorescence with anti-activated caspase-3 were used. For TUNEL staining, apoptotic cells were labelled using an in situ Death Detection Kit, POD (Roche), according to the manufacturer's instructions. The sections were also detected with NeuN and caspase-3 double-labelling immunofluorescence. The area of the hippocampus was selected for automatic quantification using Image $J$ software to detect NeuN and caspase-3 positive neurons, yielding the area fraction of the total positive staining against the area of analysed tissue. The average of the individual measurements was used to calculate group means and standard error of mean
(SEM). The quantification of the area fraction and positive cells was performed using ImageJ.

\section{Statistical analysis}

The results were presented as the mean \pm SEM. The data were first assessed for normal distribution by the one-sample Kolmogorov-Smirnov test. Statistical comparisons among groups were tested using one-way ANOVA. Two-way ANOVA was used to compare the antibody-induced time-dependent disaggregation of $A \beta$ fibrils in the ThT assay. $P$ values $<0.05$ were considered statistically significant.

\section{Results}

Antibody targeting the $\mathrm{N}$-terminus of $A \beta$ promoted the disaggregation of preformed $A \beta$ fibrils

TEM and ThT assays were conducted to investigate the capacity of antibodies to disaggregate preformed $A \beta$ fibrils. After the incubation of preformed $A \beta$ fibrils with $\mathrm{N}$-terminal antibody 6E10, which targets amino acids 1-16 of $A \beta$, truncated fibrils and small aggregates of a variable size were observed in the TEM assay (Fig. 1a). However, after the incubation with 4G8, which targets amino acids $17-24$ of $A \beta$, and $8 G 7$, which targets the $\mathrm{C}$-terminus of $\mathrm{A} \beta$ and $\mathrm{PBS}$-treated samples, highly aggregated fibrils were observed under TEM. This variance in the disaggregation ability of the antibodies was indicated by significantly lower area fractions of $A \beta$ fibrils in the $6 \mathrm{E} 10$ group ( $P=0.001$ vs PBS) (Fig. $1 \mathrm{~b}$ ).

The ThT assay was conducted to further investigate the time-dependent disaggregation of $A \beta$ fibrils induced by antibodies. A $\beta 42$ monomers were aggregated for $48 \mathrm{~h}$ and then co-incubated with antibodies for an additional $72 \mathrm{~h}$ for disaggregation. We found that the fluorescence intensity induced by $A \beta$ fibrils was significantly lower in 6E10-treated samples compared to 4G8- and 8G7-treated samples and the PBS controls (Fig. 1c).

These data suggest that an antibody against the $\mathrm{N}$ terminus of $A \beta$ was able to disaggregate $A \beta$ fibrils.

\section{Antibody targeting the $\mathrm{N}$-terminus of $\mathrm{A} \beta$ promoted the transformation of $A \beta$ fibrils to oligomers}

We next used western blot to detect whether disaggregation of $A \beta$ fibrils could facilitate the formation of $A \beta$ oligomers. After the incubation of preformed $A \beta$ fibrils with antibodies, the co-incubates were subjected to western blotting. We found that more dimers and trimers $(P<0.001$ vs PBS) and fewer fibrils $(P=0.001$ vs PBS) and aggregates with a molecular weight more than $30 \mathrm{kDa}(P=0.016$ vs $\mathrm{PBS})$ were observed in the $6 \mathrm{E} 10$ treated samples compared with the 4G8- and 8G7treated samples (Fig. 1d, e). There was no difference in the amount of A $\beta$ oligomers among the 4G8/8G7treated samples and PBS controls. These findings 


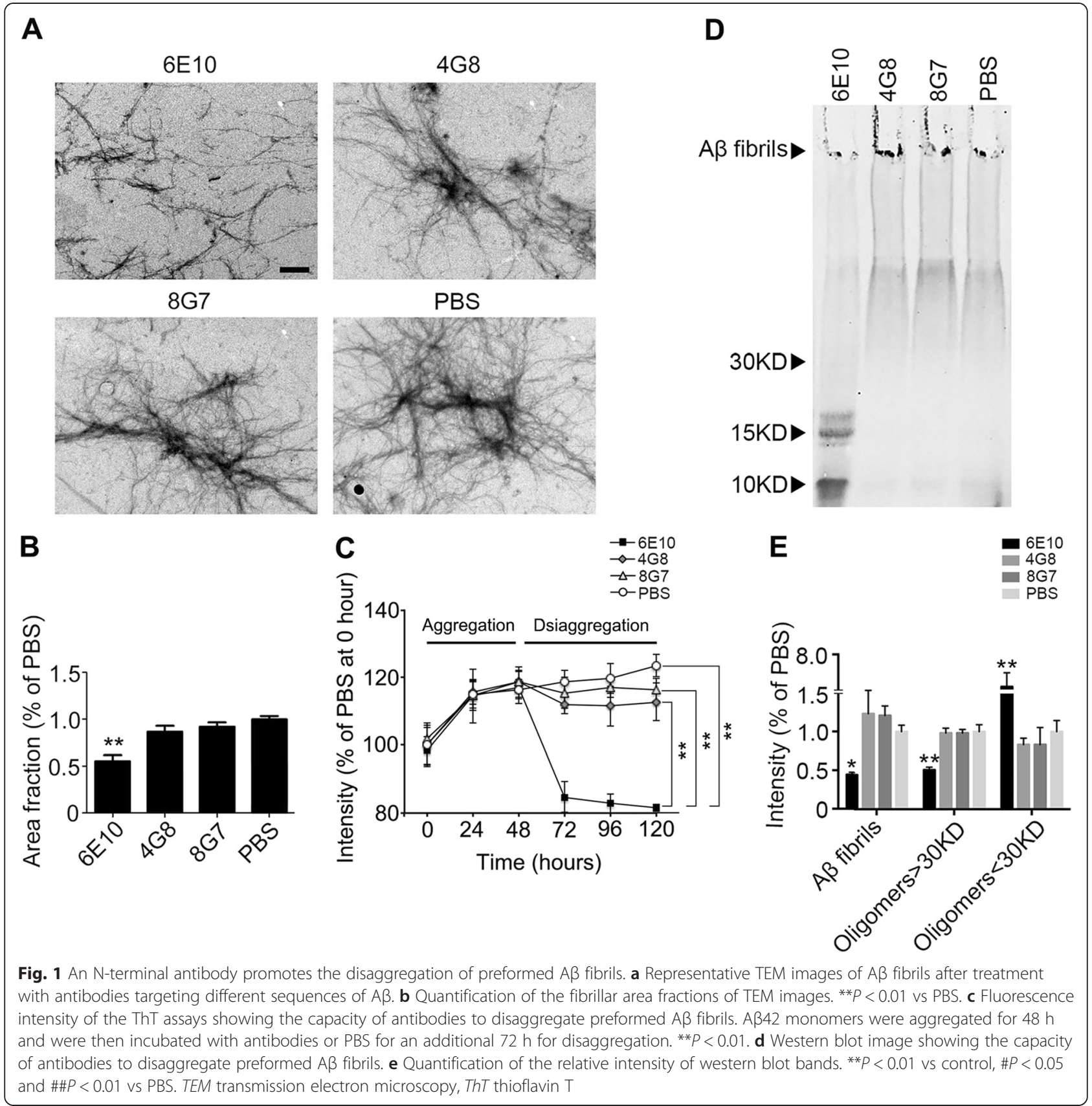

suggest that an antibody against the $\mathrm{N}$-terminus of $\mathrm{A} \beta$ facilitated the transformation of $A \beta$ fibrils into $A \beta$ oligomers.

\section{Antibody targeting the $\mathrm{N}$-terminus of $A \beta$ increased the neurotoxicity of $A \beta$ in vitro}

Based on the above findings, we proposed that the disaggregation of preformed fibrils might increase the toxicity of $A \beta$ by facilitating the formation of $A \beta$ oligomers. Annexin V staining, neurite outgrowth and MTT assays were conducted to investigate the neurotoxicities of antibody-fibril co-incubates in vitro. Interestingly, the $\mathrm{N}$ terminal antibody 6E10 significantly increased the neurotoxicity of $A \beta$ fibrils as reflected by the significant increase in the percentage of annexin V-labelled cells (Fig. 2a, b), the decrease in cell viability (Fig. 2c) and the neurite length (Fig. 2d, e) of SH-SY5Y cells. However, the percentage of annexin V-labelled cells, cell viability and neurite length were comparable among the 4G8, 8G7 and PBS groups (Fig. 2a-c). 


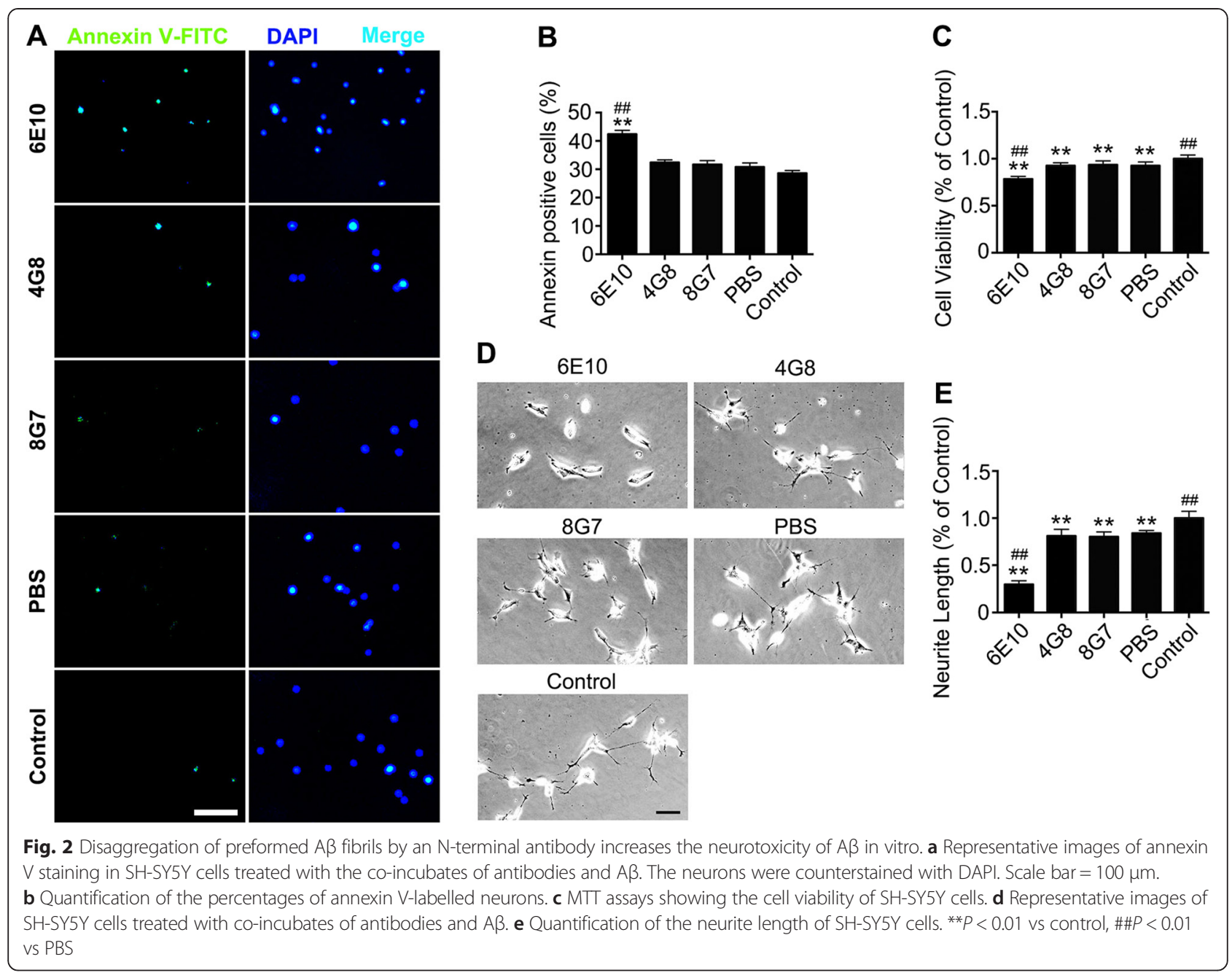

\section{Antibody targeting the $\mathrm{N}$-terminus of $A \beta$ increased the} neurotoxicity of $A \beta$ in vivo

We further investigated the neurotoxicity of $A \beta$ fibrilantibody co-incubates in vivo. After the injection of coincubates into the lateral ventricle of 6-month-old C57 mice in each group, we conducted NeuN and caspase-3 double staining, as well as TUNEL staining, to investigate the neurotoxicity in vivo. Consistent with the in vitro results, co-incubates in the 6E10 group significantly induced neuronal apoptosis in both the CA3 region $(P<0.001$ vs PBS; $P<0.001$ vs control) (Fig. 3a, b) and the dendrite gyrus $(P<0.001$ vs PBS; $P<0.001$ vs control) (Fig. 3c, d). However, no significant difference was found in neuronal apoptosis among the 4G8, 8G7 and PBS groups (Fig. 3a-d).

\section{Discussion}

In the present study, for the first time, we found that an antibody against the $\mathrm{N}$-terminus of $\mathrm{A} \beta$, but not antibodies against the middle domain or the $\mathrm{C}$-terminus of $A \beta$, disaggregated preformed $A \beta$ fibrils, leading to the formation of oligomers and enhancing the neurotoxicity of $\mathrm{A} \beta$ both in vitro and in vivo.

Immunotherapies are promising for the treatment of AD by reducing amyloid deposition and improving cognition in animal models of AD. The mechanisms of the antibody-mediated $A \beta$ clearance included solubilization of $A \beta$ fibrils $[12,13]$, antibody-mediated phagocytosis of $A \beta$ by microglia $[14,15]$ and sequestration of $A \beta$ in the blood as a peripheral "sink" [16]. However, despite their effects in reducing brain $A \beta$ deposition, immunotherapies have not been successful in improving cognition in clinical trials [17-20]. Although these failures are mainly attributed to the fact that interventions occurred too late to reverse the disease, the adverse effects associated with immunotherapies including autoimmune meningoencephalitis, vasogenic oedema and microhaemorrhage are also important factors that compromise the therapeutic efficacy of immunotherapy [4]. An important phenomenon derived from previous clinical and experimental studies is that immunotherapies are effective in reducing brain amyloid deposition but cannot reduce 

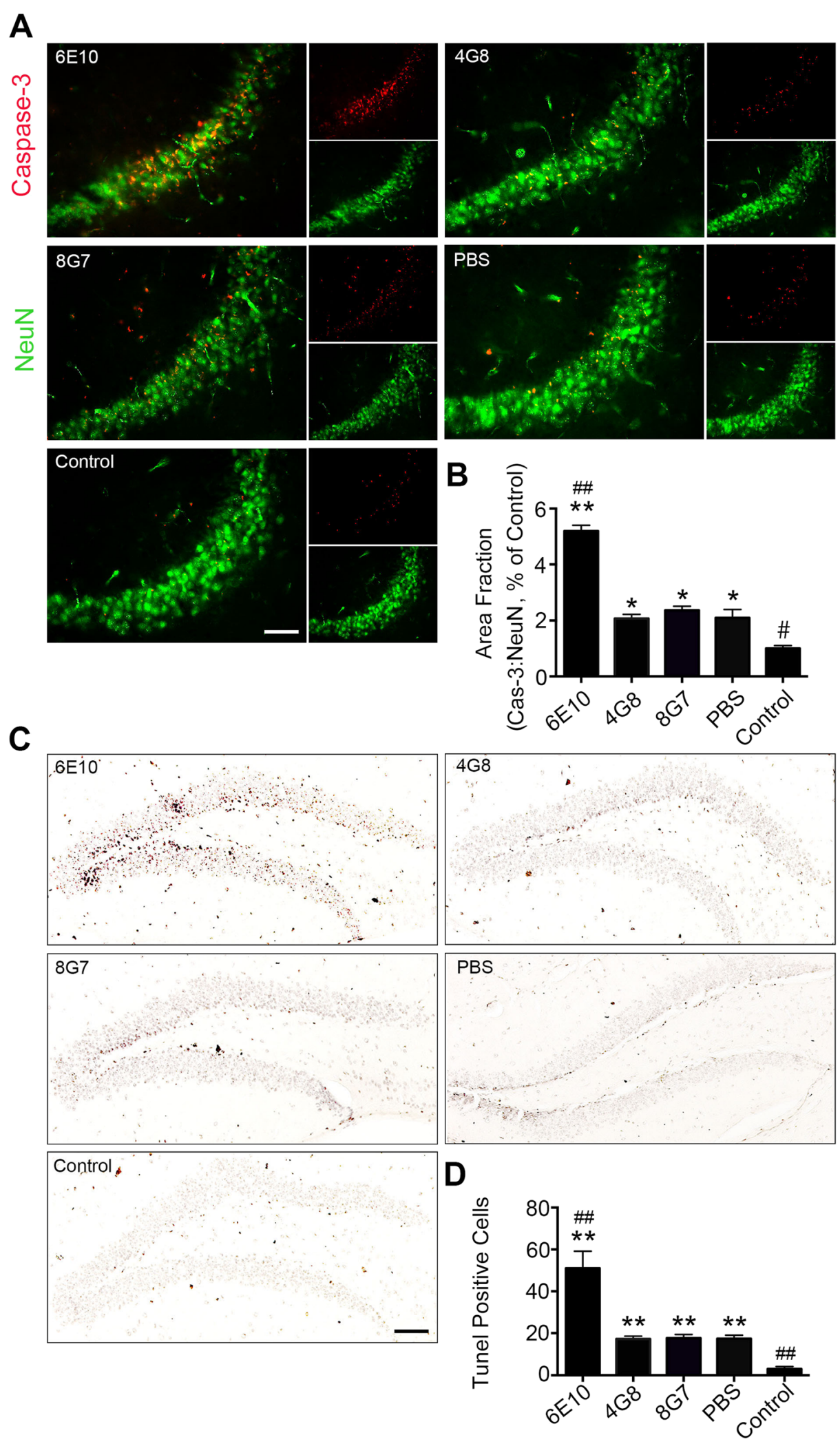

Fig. 3 (See legend on next page.) 
(See figure on previous page.)

Fig. 3 Disaggregation of preformed A $\beta$ fibrils by an N-terminal antibody increases the neurotoxicity of $A \beta$ in vivo. a Neuronal apoptosis in the CA3 region was visualized using NeuN and activated caspase-3 co-staining (scale bar $=50 \mu \mathrm{m}$ ). $\mathbf{b}$ Quantification of apoptosis by activated caspase- 3 in the CA3 region. c Neuronal apoptosis in the dendrite gyrus was visualized using TUNEL staining (scale bar $=200 \mu \mathrm{m})$. $\mathbf{d}$ Quantification of apoptotic cells in the dendrite gyrus that were stained by TUNEL ( $n=5$ per group, mean \pm SEM, One-way Anova, ${ }^{*} P<0.05$ and ${ }^{* *} P<0.01$ vs control, $\# P<0.05$ and $\# \# P<0.01$ vs PBS)

and sometimes even increase the levels of soluble $A \beta[5$, $6,21]$. The increase in soluble $A \beta$ is a result of the solubilization of $\mathrm{A} \beta$ fibrils by antibodies. Convincing data has arisen suggesting that the soluble oligomeric $\mathrm{A} \beta$ species are the primary toxic agents in $\mathrm{AD}$ [7]. Whether transformation of deposited $A \beta$ plaques into soluble $A \beta$ can favour the formation of $A \beta$ oligomers remains unknown. We have previously proposed that solubilization of $A \beta$ deposits might favour the formation of more toxic $A \beta$ oligomers, thus enhancing the neurotoxicity of $A \beta$ in immunotherapies; we have termed this phenomenon as the "dust-raising effect" [4]. In the present study, we found that an antibody against the $\mathrm{N}$ terminus of $A \beta$ (6E10) promoted the transformation of $A \beta$ fibrils into toxic oligomers, primarily $A \beta$ dimers and trimers, which are the major toxic forms of $A \beta[22,23]$ that cause significant neuronal death in the brain of mice. This finding is of significant clinical relevance. In the AN1792 trial, brain A $\beta$ deposition was removed; however, the soluble $A \beta$ species were elevated, and brain volume loss was accelerated [24]. The reason for this dissociation between $A \beta$ clearance and brain atrophy remains unclear. It was proposed that the volume changes were due to amyloid removal and associated cerebral fluid shifts [24]. According to our present findings, it is likely that the oligomeric $A \beta$ species derived from the solubilization of $A \beta$ deposits caused further damage to neurons in the brain, leading to the subsequent acceleration of brain volume loss.

In addition, the adverse effects of immunotherapies were also associated with the epitopes of the $A \beta N$-terminus. Vasogenic oedema and microhaemorrhage were observed in passive immunotherapies utilizing antibodies against the $\mathrm{N}$-terminus of $\mathrm{A} \beta$ [17] but not antibodies against the middle domain of $A \beta$ [18]. The possible reason for this is that antibodies bind to the $\mathrm{N}$-terminus of $A \beta$, which is exposed on the surface of $A \beta$ fibrils, and form immune complexes that induce subsequent inflammatory reactions $[4,25]$. We also found that antibodies to the N-terminus of $A \beta$ can promote the generation of $A \beta$ by cross-reacting with neurons via the $\mathrm{N}$-terminal epitope of $A \beta$, which is located in the extracellular domain of APP and is exposed on the surface of neurons [26, 27].

In our present study, we found that an antibody targeting the $\mathrm{N}$-terminus of $\mathrm{A} \beta$, but not antibodies to the middle domain and $\mathrm{C}$-terminus of $\mathrm{A} \beta$, was able to disaggregate $A \beta$ fibrils, suggesting that the therapeutic function of anti- $A \beta$ antibodies are closely related to their antigen epitopes. Conformational analysis showed that the $\mathrm{N}$-terminus of $\mathrm{A} \beta$ was exposed on the surface, but the middle domain and $\mathrm{C}$-terminus were embedded in the core of $\mathrm{A} \beta$ fibrils [28]. Thus, $\mathrm{N}$-terminal antibodies can potently clear $A \beta$ plaque because they are accessible to $A \beta$ fibrils, but antibodies to the middle domain and $C$ terminus of $A \beta$ may have limited potential to recognize preformed $A \beta$ fibrils and are therefore less effective as a treatment to remove $A \beta$ deposits. This notion was supported by the fact that solanezumab, an antibody against the middle domain of $A \beta$, is not as effective in reducing the brain $A \beta$ burden [18] compared to bapineuzumab, an antibody against the $\mathrm{N}$-terminus of $\mathrm{A} \beta$ that is able to remove brain $A \beta$ deposits, as evidenced by recent immunotherapeutic clinical trial $[17,29]$. It was revealed that antibodies targeting the middle domain of $A \beta$ have a better anti-aggregation capacity than those targeting the N-terminus [30]. The competency of these antibodies in antagonizing $A \beta$ aggregation can be explained by the findings that the middle domain of $A \beta$ is key for $A \beta$ aggregation [31]. In this regard, antibodies against the middle domain of $A \beta$ might be more effective as a preventative treatment before the deposition of $A \beta$.

In conclusion, the present study indicated that solubilization of $A \beta$ fibrils by an antibody against the $\mathrm{N}$-terminus of $\mathrm{A} \beta$ leads to the formation of more toxic $A \beta$ oligomeric species. The therapeutic and adverse effects of anti-A $\beta$ antibodies are associated with their antigen epitopes. This should be taken into consideration for the efficacy and safety of immunotherapies in the future.

\section{Competing interests}

The authors declare that they have no competing interests.

\section{Authors' contributions}

YJW designed the study. YHL and YJW wrote the manuscript. YHL, XLB, CRL, YRW, JD and TZ conducted the experiments. SSJ and XLB Performed the statistical analysis. FZ, JD, HDZ and XQY critically read the manuscript. All authors read and approved the final manuscript.

\section{Acknowledgements}

This study was supported by the National Natural Science Foundation of China (grant nos. 81270423, 81200987, 81471296, 81470058, 2010BB5029).

Received: 5 May 2015 Accepted: 17 August 2015

Published online: 28 August 2015 


\section{References}

1. Karran E, Mercken M, De Strooper B. The amyloid cascade hypothesis for Alzheimer's disease: an appraisal for the development of therapeutics. Nat Rev Drug Discov. 2011:10:698-712.

2. Boluda S, Toledo JB, Irwin DJ, Raible KM, Byrne MD, Lee EB, et al. A comparison of Abeta amyloid pathology staging systems and correlation with clinical diagnosis. Acta Neuropathol. 2014;128:543-50.

3. Lemere CA. Immunotherapy for Alzheimer's disease: hoops and hurdles. Mol Neurodegener. 2013;8:36

4. Liu YH, Giunta B, Zhou HD, Tan J, Wang YJ. Immunotherapy for Alzheimer disease: the challenge of adverse effects. Nat Rev Neurol. 2012;8:465-9.

5. Patton RL, Kalback WM, Esh CL, Kokjohn TA, Van Vickle GD, Luehrs DC, et al. Amyloid-beta peptide remnants in AN-1792-immunized Alzheimer's disease patients: a biochemical analysis. Am J Pathol. 2006;169:1048-63.

6. Petrushina I, Ghochikyan A, Mktrichyan M, Mamikonyan G, Movsesyan N, Davtyan $\mathrm{H}$, et al. Alzheimer's disease peptide epitope vaccine reduces insoluble but not soluble/oligomeric Abeta species in amyloid precursor protein transgenic mice. J Neurosci. 2007;27:12721-31.

7. Zhao LN, Long H, Mu Y, Chew LY. The toxicity of amyloid beta oligomers. Int J Mol Sci. 2012;13:7303-27.

8. Masliah E, Hansen L, Adame A, Crews L, Bard F, Lee C, et al. Abeta vaccination effects on plaque pathology in the absence of encephalitis in Alzheimer disease. Neurology. 2005;64:129-31.

9. Ge JF, Qiao JP, Qi CC, Wang CW, Zhou JN. The binding of resveratrol to monomer and fibril amyloid beta. Neurochem Int. 2012;61:1192-201.

10. Ramakrishnan M, Kandimalla KK, Wengenack TM, Howell KG, Poduslo JF. Surface plasmon resonance binding kinetics of Alzheimer's disease amyloid beta peptide-capturing and plaque-binding monoclonal antibodies. Biochemistry. 2009:48:10405-15.

11. Wang YJ, Valadares D, Sun Y, Wang X, Zhong JH, Liu XH, et al. Effects of proNGF on neuronal viability, neurite growth and amyloid-beta metabolism. Neurotox Res. 2010;17:257-67.

12. Solomon B, Koppel R, Frankel D, Hanan-Aharon E. Disaggregation of Alzheimer beta-amyloid by site-directed mAb. Proc Natl Acad Sci U S A. 1997;94:4109-12.

13. Bacskai BJ, Kajdasz ST, McLellan ME, Games D, Seubert P, Schenk D, et al. Non-Fc-mediated mechanisms are involved in clearance of amyloid-beta in vivo by immunotherapy. J Neurosci. 2002;22:7873-8.

14. Hack PS CE. Intravenous immunoglobulins: a treatment for Alzheimer's disease? J Neurol Neurosurg Psychiatr. 2004;75:1374-5.

15. Magga J, Puli L, Pihlaja R, Kanninen K, Neulamaa S, Malm T, et al. Human intravenous immunoglobulin provides protection against Abeta toxicity by multiple mechanisms in a mouse model of Alzheimer's disease. J Neuroinflammation. 2010;7:90.

16. Wang YJ, Zhou HD, Zhou XF. Clearance of amyloid-beta in Alzheimer's disease: progress, problems and perspectives. Drug Discov Today. 2006;11:931-8.

17. Salloway S, Sperling R, Fox NC, Blennow K, Klunk W, Raskind M, et al. Two phase 3 trials of bapineuzumab in mild-to-moderate Alzheimer's disease. $\mathrm{N}$ Engl J Med. 2014;370:322-33.

18. Doody RS, Thomas RG, Farlow M, Iwatsubo T, Vellas B, Joffe $S$, et al. Phase 3 trials of solanezumab for mild-to-moderate Alzheimer's disease. N Engl J Med. 2014;370:311-21.

19. Holmes C, Boche D, Wilkinson D, Yadegarfar G, Hopkins V, Bayer A, et al. Long-term effects of Abeta42 immunisation in Alzheimer's disease: follow-up of a randomised, placebo-controlled phase I trial. Lancet. 2008:372:216-23.

20. Senior K. Dosing in phase II trial of Alzheimer's vaccine suspended. Lancet Neurol. 2002:1:3.

21. Mably AJ, Liu W, Mc Donald JM, Dodart JC, Bard F, Lemere CA, et al. Anti-Abeta antibodies incapable of reducing cerebral Abeta oligomers fail to attenuate spatial reference memory deficits in J20 mice. Neurobiol Dis. 2015;82:372-84.

22. Hung LW, Ciccotosto GD, Giannakis E, Tew DJ, Perez K, Masters CL, et al. Amyloid-beta peptide (Abeta) neurotoxicity is modulated by the rate of peptide aggregation: Abeta dimers and trimers correlate with neurotoxicity. J Neurosci. 2008:28:11950-8.

23. Shankar GM, Li S, Mehta TH, Garcia-Munoz A, Shepardson NE, Smith I, et al. Amyloid-beta protein dimers isolated directly from Alzheimer's brains impair synaptic plasticity and memory. Nat Med. 2008;14:837-42
24. Fox NC, Black RS, Gilman S, Rossor MN, Griffith SG, Jenkins L, et al. Effects of Abeta immunization (AN1792) on MRI measures of cerebral volume in Alzheimer disease. Neurology. 2005;64:1563-72.

25. Racke MM, Boone LI, Hepburn DL, Parsadainian M, Bryan MT, Ness DK, et al. Exacerbation of cerebral amyloid angiopathy-associated microhemorrhage in amyloid precursor protein transgenic mice by immunotherapy is dependent on antibody recognition of deposited forms of amyloid beta. J Neurosci. 2005:25:629-36.

26. Deng J, Hou H, Giunta B, Mori T, Wang YJ, Fernandez F, et al. AutoreactiveAbeta antibodies promote APP beta-secretase processing. J Neurochem. 2012;120:732-40.

27. Li S, Deng J, Hou H, Tian J, Giunta B, Wang Y, et al. Specific antibody binding to the APP672-699 region shifts APP processing from alpha- to beta-cleavage. Cell Death Dis. 2014;5:e1374.

28. Colletier JP, Laganowsky A, Landau M, Zhao M, Soriaga AB, Goldschmidt L, et al. Molecular basis for amyloid-beta polymorphism. Proc Natl Acad Sci U S A. 2011:108:16938-43.

29. Liu E, Schmidt ME, Margolin R, Sperling R, Koeppe R, Mason NS, et al. Amyloid-beta 11C-PiB-PET imaging results from 2 randomized bapineuzumab phase 3 AD trials. Neurology. 2015.

30. Legleiter J, Czilli DL, Gitter B, DeMattos RB, Holtzman DM, Kowalewski T. Effect of different anti-Abeta antibodies on Abeta fibrillogenesis as assessed by atomic force microscopy. J Mol Biol. 2004;335:997-1006.

31. Millucci L, Ghezzi L, Bernardini G, Santucci A. Conformations and biological activities of amyloid beta peptide 25-35. Curr Protein Pept Sci. 2010;11:54-67.

\section{Submit your next manuscript to BioMed Central and take full advantage of:}

- Convenient online submission

- Thorough peer review

- No space constraints or color figure charges

- Immediate publication on acceptance

- Inclusion in PubMed, CAS, Scopus and Google Scholar

- Research which is freely available for redistribution 